\title{
Homozygous N396T mutation in Gaucher disease: Portuguese sisters with markedly different phenotypes
}

This article was published in the following Dove Press journal:

International Medical Case Reports Journal

I5 March 20II

Number of times this article has been viewed

\author{
Samantha Kimball ${ }^{1,2}$ \\ Francis Choy ${ }^{4}$ \\ Agnes Zay ${ }^{5}$ \\ Dominick Amato ${ }^{3}$ \\ 'Department of Nutritional Sciences, \\ University of Toronto, Canada; \\ ${ }^{2}$ Department of Laboratory Medicine \\ and Pathology, ${ }^{3}$ Department of \\ Medicine, Division of Hematology, \\ Mt Sinai Hospital, Toronto, Canada; \\ ${ }^{4}$ Department of Biology, University \\ of Victoria, Victoria, Canada; ${ }^{5}$ MRC \\ Center for Regenerative Medicine, \\ University of Edinburgh, Edinburgh, \\ Scotland
}

\begin{abstract}
Gaucher disease (GD) is characterized by reduced activity of glucocerebrosidase leading to complications in the reticuloendothelial system. N396T, a rarer mutation of the glucocerebrosidase gene, has been encountered in Portuguese populations and has generally been associated with milder phenotypes. This report presents brief histories of two Portuguese sisters, both with homozygous N396T mutations. These patients are phenotypically very different despite the fact that in both patients residual enzyme activity is very low. The case of patient 1 is complicated by comorbid diabetes mellitus and human immunodeficiency virus (HIV) infection. Enzyme replacement therapy (ERT) improved this patient's clinical picture sufficiently to enable antiretroviral treatment to proceed for the HIV. This report demonstrates the poor correlation of clinical GD with genotype as well as with residual enzyme activity. It further illustrates how treatment of the underlying GD with ERT improved symptoms allowing for antiretroviral therapy thereby improving both the GD and HIV.
\end{abstract}

Keywords: Gaucher disease, N396T mutation, glucocerebrosidase, HIV

\section{Introduction}

Gaucher disease (GD) is the most common of the lipid storage disorders. A mutation of the glucocerebrosidase (GBA) gene, located on chromosome 1q21 and encoding the lysosomal glucocerebrosidase enzyme (acid beta-glucosidase, EC.3.2.1.45), is inherited in an autosomal recessive fashion. Glucocerebrosidase is responsible for the hydrolysis of glucosylceramide to ceramide and glucose. Mutations disrupting the function of this enzyme lead to substrate accumulation in lysosomes, particularly in cells of the reticuloendothelial system. Type I GD is by far the most common form; it most often presents with hepatosplenomegaly, cytopenias, bone marrow infiltration, skeletal involvement, or a combination of these. ${ }^{1}$

In the Portuguese population the most frequent mutation is N370S (63\%), ${ }^{2}$ similar to the Ashkenazi Jewish population. Amaral et $\mathrm{al}^{3}$ demonstrated that Portuguese patients with homozygous N370S mutation present an overall milder manifestation of GD, whereas compound heterozygous patients showed no clear genotype/ phenotype correlation and ranged from clinically undetectable to severe forms of GD. Two rarer mutations, G377S and N396T are commonly encountered in the Portuguese population. ${ }^{3,4}$ The N396T mutation has been described as having the highest residual enzyme activity and a generally milder neuroprotective phenotype (although clinical heterogeneity was found). ${ }^{5}$

We report two sisters of Portuguese descent with Gaucher disease who demonstrate the following features: 1) N396T homozygosity in siblings with consanguineous parents;
Correspondence: Dominick Amato Department of Medicine, Mount Sinai Hospital, 600 University Ave, Rm 438

Toronto, Canada M5G IX5

$\mathrm{Tel}+\mathrm{I} 4165864800$

Fax +l 4165864677

Email damato@mtsinai.on.ca 
2) striking phenotypic differences in sisters with identical GBA mutations; and 3) the success of enzyme replacement therapy (ERT) in correcting the peripheral cytopenias in one of the sisters who is human immunodeficiency virus (HIV) positive, thus enabling her to receive anti-HIV therapy without the occurrence of profound cytopenias.

\section{Materials and methods}

After approval by the ethics review committee at Mount Sinai Hospital, Toronto, both subjects consented to a review and publication of their cases.

\section{$\beta$-glucosidase gene analysis}

A 254 bp fragment of exon 9 of GBA was polymerase chain reaction (PCR)-amplified with forward primer 5'CCAGTGTTGAGCCTTTGTCT3' and reverse primer 5'GAGATGATAGGCCTGGTATG3'. PCR conditions were as follows: initial denaturation for $3 \mathrm{~min}$ at $94^{\circ} \mathrm{C}, 30$ cycles of $1 \mathrm{~min}$ at $94^{\circ} \mathrm{C}, 1 \mathrm{~min}$ at $58^{\circ} \mathrm{C}$, and $1 \mathrm{~min}$ at $72^{\circ} \mathrm{C}$, and a final extension of $5 \mathrm{~min}$ at $72^{\circ} \mathrm{C}$. The PCR-amplified DNA fragments were purified using the Wizard PCR Preps DNA Purification Resin (Promega, Madison, WI). Mutation N396T creates a cleavage site for the restriction endonuclease $R s a \mathrm{I}$ (New England BioLaboratory, Ipswitch, MA) in the mutant allele. Upon PCR amplification, restriction endonuclease digestion, and electrophoresis in $8 \%$ polyacrylamide, the wild type allele will yield two DNA bands of $201 \mathrm{bp}$ and $53 \mathrm{bp}$, whereas the mutant allele will give rise to 3 DNA bands of $133 \mathrm{bp}, 68 \mathrm{bp}$, and $53 \mathrm{bp}$.

\section{Report of cases Patient I}

A female patient was diagnosed with GD in 1986, at age 43, following a liver biopsy and bone marrow aspirate (hepatosplenomegaly was also found at this time) after 20 years of uninvestigated anemia. She is a nonsmoker and does not drink alcohol. She has had four healthy children. She was told in 1986 that there was no specific treatment for her GD.

This patient was then diagnosed with HIV infection, contracted from her husband, in 1996. Septra was prescribed. Her GD complicated treatment with anti-retrovirals, as she was becoming progressively more pancytopenic, not in keeping with her HIV diagnosis, and required blood transfusions (about two transfusions per month up until November of 1996). Anti-retrovirals were discontinued in December of 1996 followed by an improvement in her blood counts. The patient did not offer the diagnosis of GD at this time; in fact, she only remembered after she was re-diagnosed with GD in January of 1997. Her beta-glucosidase level was very low at $0.1 \mathrm{nmol} / \mathrm{mg} / \mathrm{h}$ (normal WBC activity: 12.7 , interquartile range $6.4-17.7 \mathrm{nmol} / \mathrm{mg} / \mathrm{h})$.

With respect to her GD, she had chronic low back pain (worsening during the winter months), occasional night sweats, but no abdominal pain or susceptibility to infection or bleeding diathesis. Before enzyme replacement therapy (ERT) was initiated in 1997 her counts were as follows: hemoglobin $(\mathrm{Hb})$ 94-109 $\mathrm{g} / \mathrm{L}$, white cell count (WCC) $2.7 \times 10^{9} / \mathrm{L}$, neutrophils $1.7-1.9 \times 10^{9} / \mathrm{L}$, platelets $77-108 \times 10^{9} / \mathrm{L}$, and ferritin $>1500 \mathrm{ug} / \mathrm{L}$. At that time her spleen was $12 \mathrm{~cm}$ below the left costal margin and liver $8.5 \mathrm{~cm}$ below the right. DEXA scans for bone mineral density revealed diffuse osteopenia throughout the skull, cervical, thoracic, and lumbar spines, femora, and humeri. Focal areas of endosteal scalloping, lysis, and sclerosis were identified within the femurs.

ERT with the recombinant imiglucerase (Cerezyme; Genzyme, Cambridge, MA) was started at 2000 units intravenously every two weeks $(30 \mathrm{u} / \mathrm{kg})$ in May of 1997. After 3 infusions of ERT her blood counts improved with $\mathrm{Hb} 112 \mathrm{~g} / \mathrm{L}$, WCC $2.6 \times 10^{9} / \mathrm{L}$, neutrophils $2.7 \times 10^{9} / \mathrm{L}$, and platelets $79 \times 10^{9} / \mathrm{L}$. Antiretrovirals were reinitiated in May 1997 (nelfinavir $750 \mathrm{mg}$ tid, delavirdine $400 \mathrm{mg}$ tid and didanosine $125 \mathrm{mg}$ bid) and were well tolerated. In July of 1997 her viral load was $<500$ copies/mL (down from 53,000 copies/mL in March) with a CD4 count of 129 and a stable $\mathrm{Hb}$ at $114 \mathrm{~g} / \mathrm{L}$.

She suffered a compression fracture of the 12th thoracic vertebra due to the GD in July of 1997. Bony pain has occurred in her right ankle, tibia, lower back, legs, and hips. She also experienced scalp tenderness and pain in her teeth, which led to full dental extractions. In the summer of 1999 she developed a frozen shoulder leading to a rigorous physiotherapy regimen. In February of 2000 she fractured her right tibia as a result of a fall. Treatment of the break consisted of a leg cast and physiotherapy.

She contracted a herpes zoster infection in 1999, which was treated with 7 days of acyclovir. In 2003, a urinary tract infection was successfully treated.

She was diagnosed with type II diabetes mellitus in November of 2004 and remains on dietary control for this. At last check her fasting blood glucose was $4.4 \mathrm{mmol} / \mathrm{L}$ with $\mathrm{HbAlc}$ at $5.0 \%$. There is a family history of type II diabetes, including her mother, father, 2 sisters, and her brother.

Her dose of 2000 units biweekly ( $30 \mathrm{u} / \mathrm{kg}$, May 1997) was lowered to 1600 units biweekly (March 1998), and lowered further to her current dose of 1200 units biweekly in June 
2001 until it was interrupted in August 2009 due to enzyme shortages. ERT was reinitiated in January 2010 at 1600 units biweekly and was then reduced to 1200 units biweekly in June 2010. Though her bony pain (lower back) and hepatosplenomegaly persist, she is quite stable on her regimen of ERT and antiretrovirals (nelfinavir, delavirdine, and abacavir which replaced didanosine in November 2001).

At her last visit (2010) her weight was $68.1 \mathrm{~kg}$, blood pressure 148/80, and her spleen was palpable $5 \mathrm{~cm}$ below the left costal margin. Her blood counts were essentially normal: $\mathrm{Hb} 129 \mathrm{~g} / \mathrm{L}$, WCC $3.0 \times 10^{9} / \mathrm{L}$ (neutrophils $1.3 \times 10^{9} / \mathrm{L}$ ), and platelets $162 \times 10^{9} / \mathrm{L}$.

An MRI of her abdomen revealed a liver volume of $1723 \mathrm{~mL}$ (1913 mL in 2003) and a spleen volume of $389 \mathrm{~mL}$ (547 mL in 2003). DEXA scan in January 2006 showed severe osteoporosis of the lumbar spine and left femoral neck, with a high risk of fracture (unchanged from previous report).

Virologically and immunologically she remains stable. In September 2010 her viral load was $<50$ with a CD4 count of $406 / \mu \mathrm{L}$.

\section{Patient 2}

A 48-year-old woman was diagnosed with GD in 1998 upon recommendation due to her sister's (patient 1) diagnosis. Like her sister, she is a nonsmoker and does not drink alcohol. She has a healthy son and daughter.

This patient is overweight at $72.5 \mathrm{~kg}$ with a blood pressure of 106/64 mmHg. Her blood counts were normal: $\mathrm{Hb}$ $113 \mathrm{~g} / \mathrm{L}$, WCC $5.5 \times 10^{9} / \mathrm{L}$, neutrophils $3.5 \times 10^{9} / \mathrm{L}$, and platelets $159 \times 10^{9} / \mathrm{L}$; as were her routine chemistries, with the exception of a high serum ferritin at $775 \mu \mathrm{g} / \mathrm{L}$. Measurement of white blood cell beta-glucosidase activity in 1998 revealed it to be $0.1 \mathrm{nmol} / \mathrm{mg} / \mathrm{h}$.

Her liver volume was measured at $1785 \mathrm{~mL}$ (high normal volume; $1680 \mathrm{~mL}$ in 2008). Of interest, her splenic volume was measured at $75 \mathrm{~mL}$ on two separate occasions (2003 and 2010), which is small; normal for her size should be 160-170 mL. On skeletal survey and MRI, her femurs show the typical Erlenmeyer flask deformity of GD but no other major abnormalities were seen (2009). DEXA scans for bone marrow density (2009) revealed osteopenia in the spine and femoral neck. Her only medication is lisinopril/ hydrochlorothiazide for hypertension.

This patient does complain of occasional bone pain in her back and legs with prolonged activity. She denies any abdominal discomfort, fevers, night sweats, or appetite problems and her energy level is good. She has a history of iron deficiency anemia that has responded to iron supplementation, but no other cytopenias. She denies any bleeding, bruising, or frequent infections. Past history is remarkable for hypertension, migraines, and previous cesarean section.

So far, her disease remains almost without clinical manifestation and she is physically asymptomatic. She has had no hospitalizations, operations, or significant illnesses.

She and her sister share the same two parents, who themselves are second cousins. A comparison of the patients' clinical findings is presented in Table 1.

\section{Discussion}

There are several points of interest to note about the two case reports outlined. The first is the extremely different phenotypes presented by the two sisters. Both patients show very little beta-glucosidase activity. In the first case, the patient suffers from migrating bony pain and hepatosplenomegaly. She was also anemic, neutropenic, and thrombocytopenic before starting ERT. In the case of the second patient these findings are absent and her GD likely would have gone undetected and undiagnosed had it not been for the findings in her sister's case. There is often poor correlation between genotype and phenotype ${ }^{6}$ in GD and these sisters are but another example.

Second, patient 2 has an exceptionally small splenic volume at $75 \mathrm{~mL}$; for her size the normal volume is in the range of $160-170 \mathrm{~mL}$. We were unable to find any report with similar findings in a patient with GD.

The third remarkable aspect is the complication of HIV infection in patient 1 . The first attempt at antiretroviral

Table I Comparison of two Portuguese sisters diagnosed with Gaucher disease

\begin{tabular}{|c|c|c|c|}
\hline Case report & Patient I & & Patient 2 \\
\hline Sex & $\mathrm{F}$ & & $\mathrm{F}$ \\
\hline Current age & 67 & & 60 \\
\hline \multirow[t]{3}{*}{ ERT (yr started) } & Yes (1997) & & No \\
\hline & Pretreatment & Post-ERT & \\
\hline & $(1997)$ & $(2010)$ & \\
\hline Spleen (cm below LCM) & $18.5 \mathrm{~cm}$ & $5 \mathrm{~cm}$ & Normal \\
\hline Volume $(\mathrm{mL})$ & ND & 389 & 75 \\
\hline Liver (cm below RCM) & $18 \mathrm{~cm}$ & Normal & Normal \\
\hline Volume (mL) & ND & 1723 & 1785 \\
\hline Hemoglobin (g/L) & $94-109$ & 129 & 117 \\
\hline White blood cells $\left(\times 10^{9} / \mathrm{L}\right)$ & 2.7 & 3.0 & 5.9 \\
\hline Neutrophils $\left(\times 10^{9} / \mathrm{L}\right)$ & $1.7-1.9$ & 1.3 & 3.9 \\
\hline Platelets $\left(\times 10^{9} / \mathrm{L}\right)$ & $77-108$ & 162 & 172 \\
\hline Ferritin $(\mu g / L)$ & $>1500$ & 661 & 867 \\
\hline
\end{tabular}

Abbreviations: ERT, enzyme replacement therapy; LCM, left costal margin; RCM, right costal margin; ND, not done; organ volumes were not measured in our institution before 2001 . 
therapy resulted in worsening of the patient's cytopenias due to the underlying GD. Although this patient would not have met the criteria for enzyme replacement therapy in our province (Ontario) under normal circumstances, ${ }^{6}$ her need for antiretroviral treatment without marked diminution of her blood counts prompted the Gaucher Treatment Review Committee of Ontario to make an exception and recommend ERT. The provincial government of Ontario approved the recommendation for ERT. ERT ultimately enabled her to resume treatment with antiretrovirals, and both treatments are well tolerated by the patient.

Some inborn errors of metabolism, for example mucopolysaccharidosis, exhibit good correlation between residual enzyme activity ( $\alpha$-L-iduronidase) and genotype as well as with the biochemical phenotype throughout the clinical course of this lysosomal storage disorder. ${ }^{7}$ In GD we may assume that the highest residual enzyme activity may result in the mildest phenotype. In the cases presented here both patients have a beta-glucosidase level of $0.1 \mathrm{nmol} / \mathrm{mg} / \mathrm{h}$ as well as being homozygous for the N396T GBA gene mutation, indicating that phenotype is not related to either the specific genetic mutation or to the level of residual enzyme activity.

\section{Disclosure}

No conflicts of interest were declared in relation to this paper.

\section{References}

1. Charrow J. Enzyme replacement therapy for Gaucher disease. Expert Opin Biol Ther. 2009;9(1):121-131.

2. Lacerda L, Amaral O, Pinto R, Oliveira P, Aerts J, Sa Miranda MC. Gaucher disease: N370S glucocerebrosidase gene frequency in the Portuguese population. Clin Genet. 1994;45(6):298-300.

3. Amaral O, Lacerda L, Santos R, Pinto, RA, Aerts H, Sa Miranda MC. Type 1 Gaucher disease: molecular, biochemical, and clinical characterization of patients from northern Portugal. Biochem Med Metab Biol. 1993;49(1):97-107.

4. Amaral O, Lacerda L, Marcao A, Pinto E, Tamagnini G, Sa Miranda MC. Homozygosity for two mild glucocerebrosidase mutations of probably Iberian origin. Clin Genet. 1999;56(1):100-102.

5. Amaral O, Marcao A, Sa Miranda MC, Desnick RJ, Grace ME. Gaucher disease: expression and characterization of mild and severe acid betaglucosidase mutations in Portuguese type 1 patients. Eur J Hum Genet. 2000;8(2):95-102.

6. Amato D, Stachiw T, Clarke JT, Rivard GE. Gaucher disease: variability in phenotype among siblings. J Inherit Metab Dis. 2004;27(5): 659-669.

7. Bunge S, Clements PR, Byers S, Kleijer WJ, Brooks DA, Hopwood JJ. Genotype-phenotype correlations in mucopolysaccharidosis type 1 using enzyme kinetics, immunoquantification and in vitro turnover studies. Biochim Biophys Acta. 1998;1407(3):249-256.
International Medical Case Reports Journal

\section{Publish your work in this journal}

The International Medical Case Reports Journal is an international, peer-reviewed open-access journal publishing original case reports from all medical specialties. Previously unpublished medical posters are also accepted relating to any area of clinical or preclinical science. Submissions should not normally exceed 2,000 words or

\section{Dovepress}

4 published pages including figures, diagrams and references. The manuscript management system is completely online and includes a very quick and fair peer-review system, which is all easy to use. Visit $\mathrm{http}: / / \mathrm{www}$.dovepress.com/testimonials.php to read real quotes from published authors. 